\begin{tabular}{c} 
Volume and Issues Obtainable at Center for Sustainability Research and Consultancy \\
Journal of Accounting and Finance in Emerging Economies \\
ISSN: 2519-0318 ISSN (E) 2518-8488 \\
Volume 5: Issue 1 June 2019 \\
JSRᄃ \\
Journal homepage: $\underline{\text { www.publishing.globalcsrc.org/jafee }}$ \\
\hline
\end{tabular}

\title{
CPEC Investment Opportunities and Challenges in Pakistan
}

\author{
${ }^{1}$ Salman Masood Sheikh, ${ }^{2}$ Mahwish Zafar, ${ }^{3}$ Saqib Nawaz, ${ }^{4}$ Asma Nawaz \\ ${ }^{1}$ Associate Professor, The Superior College, Lahore, Pakistan, Email: directorqa@ superior.edu.pk \\ ${ }^{2}$ Assistant Professor, The Superior College, Lahore, Pakistan. Email: mahwish.zafar@ superior.edu.pk \\ ${ }^{3}$ Lecturer, National Collage of Business Administration \& Economics, Lahore, Pakistan. \\ Email: saqibnawaz09@gmail.com \\ ${ }^{4} \mathrm{PhD}$ Scholar, Faculty of Business, Economics and Communication, Neresuan University, Phitsanulok, Thailand \\ aa.asmanawaz@gmail.com
}

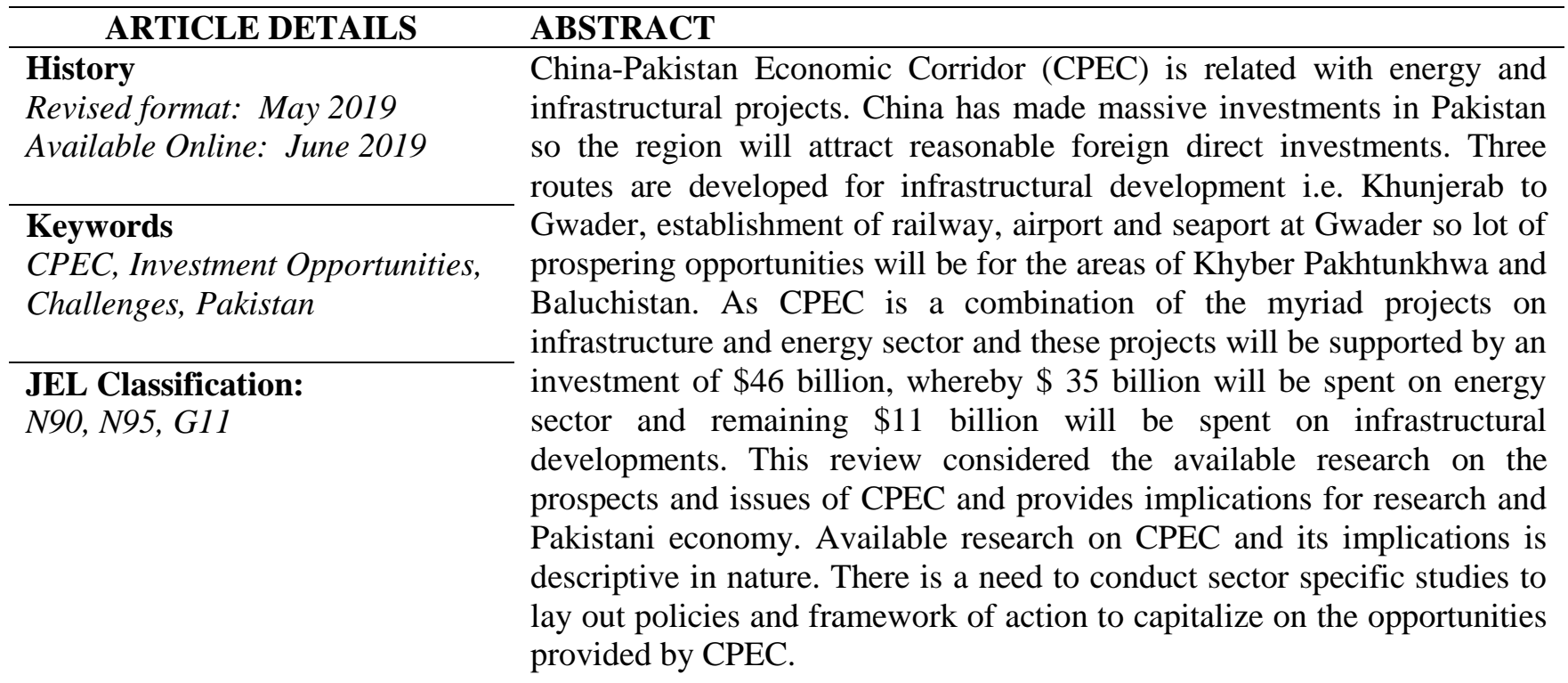

(C) 2019 The authors, under a Creative Commons Attribution-Non

Commercial 4.0

Corresponding author's email address: directorqa@ superior.edu.pk

Recommended citation: Sheikh, S. M., Zafar, M., Nawaz, S. and Nawaz, A. (2019). CPEC Investment Opportunities and Challenges in Pakistan. Journal of Accounting and Finance in Emerging Economies, 5 (1), 123-128

DOI: $10.26710 /$ jafee.v5i1.722

\section{Introduction}

CPEC is a combination of infrastructural and energy related projects, whereby China directly or indirectly has committed a massive investment of $\$ 46$ billion. Hali et al. (2015) quoted that investments on CPEC and related projects will bring more inflows to Pakistan over next 15 years, comparing the total inflows of the country since 1970.CPEC is being considered a 'Game Changer' for the Pakistan, which at the moment is facing many difficulties to uphold to its economic prospects. The first and foremost problem of Pakistan is its electricity outrage, which is addressed by CPEC by incorporating power generation projects with capacity of $15000+\mathrm{MW}, 74 \%$ of the existing power generation capacity of the country. Out of total $\$ 46$ billion, an approximate amount of $\$ 34$ billion 
will be spent on the revival of energy sector of Pakistan (BMA, 2015). Further, infrastructural developments, establishment of the special economic zones and development of the Gwader Port are added benefits of the CPEC. Gwader Port has its own geo-political and economic significance, not only for Pakistan, but also for China and other neighboring countries. The development of the Gwader Port started prior to the announcement of CPEC in 2002. An initial allocation of $\$ 700$ million is made for the development of Gwader Port under CPEC agreement (BMA, 2015). According to Khan (2013), Gwader port has potential to generate billions in revenue and could support employment of more than 2 million jobs in the country. Haq and Farooq (2016) also provided positive projections of CPEC on social welfare of the country, specifically for those districts, which are located on CPEC routes. Social welfare dimensions probed in the study are related to education, health and housing along with living standards and poverty. Thus, a massive and positive impact of the CPEC is being propagated on the economy of Pakistan, and CPEC is being considered a 'Game Changer', which would ensure a long term sustainable growth of the economy of the country.

Apart from the positive implications of CPEC for the economy of Pakistan, there have been certain internal challenges, which might hinder the true potential of CPEC. These challenges are related to the internal issues like security concerns, interprovincial agreement \& harmony, political uncertainty and administrative concerns (Abid \& Ashfaq, 2015; Hussain, 2016) and also external issues like competition for dominance and economic benefits with India and Iran, proxy wars in the region and climate issues (Vandewalle, 2015;Hussain, 2016; Huang, Fischer\& Xu, 2016). Although CPEC has just started and its initial harvest projects are due in early 2018, there have been a lot of debate as to whether the project will deliver to its expectations in terms of economic and social development, or it will unfold another controversy like Kala Bagh Dam (Mengal, 2016). This review in this regard provides a comprehensive overview of CPEC and its economic implications for Pakistan. This review is organization as follows: first of all, a general conception of economic corridors and special economic zones is provided, after that a detailed description of CPEC is made, subsequently economic implications of CPEC are discussed and after that challenges to successful implementation of CPEC are highlighted. Lastly, concluding remarks are made and implications for future research are provided.

\section{Economic corridors and ASEAN Countries}

Ishida (2009) in this regard provided the case of China and ASEAN countries, whereby the economic development of the region has been ensured by establishment of special economic zones and open coastal cities. These areas also have attracted massive foreign direct investments as these areas have easy access to port or harbor, and cheap supply of labor. Further, their interconnectivity through roads and other infrastructural facilities is quite good and tax incentives are provided to the industrialists in the area. Ishida (2009) Exemplified economic corridors in Greater Mekong Sub Region, whereby Laos, Thailand, Myanmar, China, Vietnam, Bangkok and Cambodia are interconnected through three economic corridors and highlighted importance of building industrial hubs for reaping benefits from economic corridors. Hussain (2016), on the other hand related economic corridors of Africa to 'engines of growth', whereby such corridors have facilitated trade and provided employment opportunities to the people.A need for the governing legislative framework is also stressed in this regard like Intermodal Surface Transport Efficiency Act of 1990 and NAFTA of 1994, which aimed at supporting the economic corridor and trade between Canada and USA.

\section{CPEC and related Investments}

Infrastructural component of the project will be based on the development of three routes from Khunjerab to Gwader, establishment of railway, airport and seaport at Gwader. These infrastructural and power related projects are distributed evenly among all geographical regions of Pakistan, and there are a lot of prospering opportunities for neglected areas of Khyber Pakhtunkhwa and Baluchistan. Further, establishment of mineral processing zones, industrial processing zones and industrial parks is also part of CPEC and a total of \$46 billions would come to the country (Hussain, 2015). The project also has expansion potential as other countries in the region could also have access to the trade routes and to the port of Gwader. Butt and Butt (2015), in this regard quoted Chinese President Jinping who iterated that, "The planning and layout of the Economic Corridor should cover other parts of Pakistan as well so that the fruits of its development will reach both all the people in Pakistan and the people of other countries in our region". Thus, CPEC could not only provide economic and regional integrational benefits to Pakistan, but also other countries in the region could have access to it and reap mutual benefits of trade, peace and harmony. 


\section{CPEC - Details of projects}

As related previously, that CPEC is a combination of the myriad projects on infrastructure and energy sector and these projects will be supported by an investment of $\$ 46$ billion, whereby $\$ 35$ billion will be spent on energy sector and remaining \$11 billion will be spent on infrastructural developments (Rafi, Khan \& Aslam, 2016).Out of this \$46 million, China will spend around \$28 billion in shape of foreign direct investment, while remaining \$18 billion will be Pakistan's share, which will also be advanced by China on concessional rates (BMA, 2015).The early harvest projects have timeline of five years, while other long term projects will take ten to fifteen years in completion (Hussain, 2016). Table 3.2.1 below provides initial breakup of the approximate costs and nature of the investments in energy, infrastructure and Gwader based projects as provided by board of investment (boi) of Pakistan.

Table 4.1 Project Breakup

\begin{tabular}{|l|l|l|l|}
\hline Sr. No. & Sector & No. of Projects & Estimated Cost (Million \$) \\
\hline 01 & Energy & 21 & 33,793 \\
\hline 02 & Transport Infrastructure & 4 & 9,784 \\
\hline 03 & Gwadar & 8 & 792.62 \\
\hline
\end{tabular}

Source: http://boi.gov.pk/InfoCenter/CPEC.aspx

A relatively more elaborated breakup of the investments was provided by BMA (2015) research in their report, which is provided in table 3.2.2. The breakup elaborated that energy is main focus of CPEC, while infrastructure, rail and Gwader port are relatively small parts of the overall investments. Appendix A to D provides a detailed overview of the projects associated with Energy, transportation infrastructure, Gwadar port and also details on the industrial coordination projects like establishment of the special economic zones.

Table 4.2 Investment Breakup - CPEC Projects

\begin{tabular}{|l|l|l|l|l|}
\hline Project Type & & $\begin{array}{l}\text { Total Investment } \\
(\$ \mathrm{Bn})\end{array}$ & Domestic Share $(\%)$ & $\begin{array}{l}\text { Domestic Share }(\$ \\
\text { Bn) }\end{array}$ \\
\hline Energy & & 33.8 & & \\
\hline Coal & $7,560 \mathrm{MW}$ & 8.8 & $20 \%$ & 1.8 \\
\hline Wind & $200 \mathrm{MW}$ & 0.5 & $20 \%$ & 0.1 \\
\hline Hydel & $1590 \mathrm{MW}$ & 4.2 & $50 \%$ & 2.1 \\
\hline Solar & $1000 \mathrm{MW}$ & 1.7 & $0 \%$ & - \\
\hline Second Phase & $6445 \mathrm{MW}$ & 9.5 & $20 \%$ & 1.9 \\
\hline Mining Expenditure & & 9.0 & $50 \%$ & 4.5 \\
\hline Road & & 5.9 & $80 \%$ & 4.7 \\
\hline Rail & 3.7 & $50 \%$ & 1.8 \\
\hline Mass Transit in Lahore & & 1.5 & $50 \%$ & 0.8 \\
\hline Gwader Port & & 0.7 & $50 \%$ & 0.3 \\
\hline China Pak Fiber Optics & & 0.0 & $0 \%$ & - \\
\hline
\end{tabular}

Source: BMA (2015)

First and foremost significant part of the CPEC projects is related to power generation. Pakistan is short of its energy demand and there exist a shortfall of \$4,500 MW. CPEC energy investments would enable Pakistan to overcome this shortfall as it is is expected that production capacity of Pakistan will increase by more than 10,000 MW by 2018 and by the completion of the project in 2030, this investment would have contributed a total of 16,400 MW into national grid (Rafi, Khan \& Aslam, 2016). These projects include establishment of coal power plants, wind farms, hydropower stations and solar power parks as the focus of these projects is to produce power at cheap rates, thus higher priority is being given to the coal generated power in the project (BMA, 2015).

\section{Issues \& Challenges}


Prospects of CPEC are not without perils and challenges. These issues and challenges could be categorized into internal and external challenges (Abid \& Asfaq, 2015; Hussain, 2016). Abid and Ashfaq (2015) quoted the Chinese view on these issues which indicated towards administrative issues, security concerns and political instability could prove to major challenges for successful implementation of CPEC. Provincial rifts and concerns of different political parties are another issue in this regard. While external factor included geopolitical rifts in the area, development of Chabahar port in Iran,

\subsection{Internal Issues \& Challenges}

Internally, Pakistan is plagued by corruption and administrative inefficiencies. China has raised serious issues over such administrative glitches, whereby Federal Board of Revenue (FBR) is said to purposely delaying the tax exemption process of imported equipment, used for CPEC (Abid \& Ashfaq, 2015). Wolf (2016) also indicated towards poor administrative capacities, corruption and lack of transparency of Pakistan, which could significantly delay mega projects and also cause project implementation cost to rise. Gul (2015) indicated towards poor law and order situation and infrastructural problems in Khyber Pakhtunkhwa and Baluchistan, which can hider development of CPEC. Internal security situation is also an issue, whereby terrorism has caused serious damage to the local society, and the massive infrastructure of CPEC could easily be harmed, and there would be additional costs to ensure security of the CPEC project, which could cause a slowdown in expected economic growth of the country (Hussain, 2016).

Further, political parties of different provinces have raised concerns over the implementation plan of CPEC and it is alleged that more benefits are secured by Punjab province, while Khyber Pakhtunkhwa and Baluchistan provinces will not be able to reap enough benefits from the project. Abid and Asfaq (2015) pointed out that all major political parties of these two provinces are voicing their concerns, while separatists in Baluchistan are altogether against CPEC. There had been incidents of violence, kidnappings and killings against Chinese working in Baluchistan from Baloch extremists to derail CPEC developments. Even the governments in power of these two provinces have raised concerns (Hussain, 2015). Wolf (2016) in this regard iterated that Pakistan has tendency of ruining good development projects due to political tussles and lack of vision. A relevant example quoted in this regard is of Kalabag Dam (Mengal, 2016; Wolf, 2016).

Wolf (2016) also indicated towards some geographical and climate issues, whereby it is difficult to build good infrastructure at mountain areas and some of the gateways like Khunjrab pass remain closed half of the year due to heavy snowfall. Lastly, there are some environmental concerns to address, as research indicate that such economic corridors have a negative impact on the environment of the region due to increased carbon emission and land deteriorations (Ishida, 2009; Huang, Fischer \& Xu, 2016; Shaikh, Ji \& Fan, 2016), which should be dealt in an appropriate manner by all the stakeholders.

\subsection{External Issues and Challenges}

Externally, there have been geo-political and regional conflicts of Pakistan with India, Iran and UAE, which might join hands to hamper development of the CPEC. CPEC is being considered an effort of China to increase its influence in Indian ocean, which is being considered a threat by India and also USA (Wolf, 2016). Further, CPEC has tremendous implications for Gilgit-Baltistan and Azad Kashmir, which at present are disputed territories and India also have claims to these territories. CPEC could formally incorporate these territories into Pakistan, which would not be acceptable for India (Wolf, 2016). Apart from this, CPEC is expected to spur economic competition of Pakistan with Iran and India in the region (Hussain, 2016). Thus, India and Iran have joined hands to develop Chabahar port in Iran to counter that (Mullen, 2012). Sabena (2014) also indicated that Russia has monopoly in central Asia states, which are land locked, CPEC provides these states an opportunity to get free from the monopoly of Russia, which would be against Russian interests. An ongoing proxy war in Afghanistan could also pose a serious threat for CPEC and hinder its benefits for the region (Wolf, 2016; Hussain, 2016). Port of Gwader has potential to become regional trade hub, which pose a serious threat for UAE, whereby a fully operational Gwader port will cause Dubai to lose almost $70 \%$ of its business (Butt \& Butt, 2015).

Despite a threat to USA and Russian, both of the world powers have not opposed CPEC, although there have been certain attempts of USA to refrain Pakistan handing over operational control of Gwader to China (Butt \& Butt, 2015). 
The external issues of CPEC are myriad of geo-political and economic concerns of various regional and nonregional stakeholders, which could effectively be dealt by a strong foreign policy, at which Pakistan is at a serious discredit as of now (Smejo, 2016; Herald, 2016).

\section{Conclusion}

CPEC as perceived from this review is a multilateral opportunity for Pakistan, which has economic and social implications. On economic side, it will bring FDI into Pakistan immediately, afterwards regional trade will be promoted through it and economy of Pakistan revive in the order. Further, people of Pakistan will find employment, economic zones will be built, and physical infrastructure will be improved, which will uplift overall economy of the country in a sustainable manner. Thus, economic prospects of CPEC are quite promising for the future of Pakistan. Further, there are certain internal and external issues, which could cause serious damage by hindering the prospects and implications of CPEC. These include internal issues like administrative inefficiencies, political rifts, poor infrastructural and transportation capabilities, security concerns and law \& order situation and external geopolitical and regional conflicts of interests and power with India, Iran, UAE, USA and Russia. A systematic approach should be adopted to gradually build the capacity to solve internal issues and a strong foreign policy should be devised and pursed to minimize external ones. Further, policy makers should seriously focus on the development of capacity to cultivate a skilled workforce, much needed to sustain the projects of CPEC and their subsequent economic impact in the long run.

\section{References}

Abid, M., \& Ashfaq, A. (2015). CPEC: Challenges and Opportunities for Pakistan. Pakistan Vision, 16(2).

BMA (2015). Pakistan Economy: Impact of China Pak Economic Corridor - A Bird's Eye View. BMA Capital Management Limited. http://investorguide360.com/wp-content/uploads/2015/05/Impact-of-China-PakEconomic-Corridor_-A-Birds-Eye-View.pdf

Butt, K. M., \& But, A. A. (2015). Impact of CPEC on regional and extra-regional actors. Journal of Political Science, XXXIII, 23-44

Gul, I. (2015). Pakistan, China and the economic corridor. The Express Tribune. Available from http://tribune.com.pk/story/854706/pakistan-china-and-the-economic-corridor/.

Hali, S. M., Shukui, T., \& Iqbal, S. (2015). One Belt and One Road: Impact on China-Pakistan Economic Corridor. Institute of Strategic Studies, Islamabad. http://www.issi.org.pk/wpcontent/uploads/2015/12/Shafei_Moiz_and_Tan_and_Sumera_3435_SS_41_20142015.pdf

Haq, R., \& Farooq, N. (2016). Impact of CPEC on Social Welfare in Pakistan: A District Level Analysis. Paper Presented at 32nd Annual General Meeting and Conference, Pakistan Society of Development Economists, Pakistan Institute of Development Economics.

Herald (2016). Pakistan's foreign policy betrays deep domestic insecurities. DAWN. Accessed from http://herald.dawn.com/news/1153426.

Huang, Y., Fischer, T. B., \& Xu, H. (2016). The stakeholder analysis for SEA of Chinese foreign direct investment: the case of 'One Belt, One Road'initiative in Pakistan. Impact Assessment and Project Appraisal, 1-14.

Huang, Y., Fischer, T. B., \& Xu, H. (2016). The stakeholder analysis for SEA of Chinese foreign direct investment: the case of 'One Belt, One Road'initiative in Pakistan. Impact Assessment and Project Appraisal, 1-14.

Hussain, E. (2016). China-Pakistan Economic Corridor: Will It Sustain Itself?. Fudan Journal of the Humanities and Social Sciences, 1-15.

Hussain, I. (2015).

Hussain, I. (2015). China Pakistan Economic Corridor. https://ishrathusain.iba.edu.pk/speeches/china-pakistaneconomic-corridor.docx.

Irshad, M. S. Xin, Q. \& Arshad, H. (2015). One Belt and One Road: Dose China-Pakistan Economic Corridor Benefit for Pakistan's Economy? Journal of Economics and Sustainable Development, 6 (24).

Ishida, M. (2009). Special economic zones and economic corridors. ERIA Discussion Paper Series, 16.

Khan, Z. A. (2013). China's Gwadar and India's Chahbahar: an analysis of Sino-India geo-strategic and economic competition. Journal of Strategic Studies, 32. 
Mengal, S. (2016). CPEC Route Controversy: Problems and Opportunities. Balochistan Review, XXXV (2), 23-30.

Mullen, R. D. (2012). India flexes its foreign aid muscle. Current History, 111, 154-155.

Rafi, A., Khan, F., \& Aslam, S. (2016). CPEC: Pakistan's way to success. IICR Special Report. http://iicr.org.pk/wp-content/uploads/2016/09/IICR-Special-Report-on-CPEC.pdf

Sabena, S. (2014). Gawadar: China's string of pearls. Opinion Maker. Available from http://www.primeinstitute.org/uploads/2/3/2/3/23230278/pak-china_economic_corridor-_1.pdf.

Shaikh, F., Ji, Q., \& Fan, Y. (2016). Prospects of Pakistan-China Energy and Economic Corridor. Renewable and Sustainable Energy Reviews, 59, 253-263.

Smejo, D. H. (2016). Why Pakistan's Foreign Policy Is So Confused. The Diplomat. Accessed from http://thediplomat.com/2016/08/why-pakistans-foreign-policy-is-so-confused/

Vandewalle, L. (2015). Pakistan and China: 'Iron brothers' forever?. Policy Department, Directorate-General for External Policies, European Union.

Wolf, S. O. (2016). The China-Pakistan Economic Corridor: An Assessment of its Feasibility and Impact on Regional Cooperation. South Asia Democratic Forum Working Paper. 